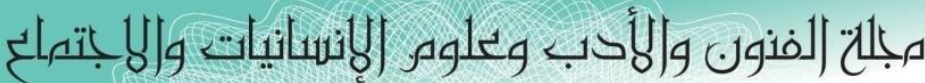

Journal of Arts, Literature, Humanities and Social Sciences

ISSN online: 2414 - 3383

ISSN print: 2616 - 3810

أيلول -سبتهبر 2019

العدد (42)

\title{
An Analysis of "To Kill a Mockingbird" through the Lens of Critical Race Theory*
}

\author{
Lecturer : Kayghan Mohamad MohamadAmin
}

Department of English Language/College of Languages/Salahaddin University /Erbil kayghanbeg@gmail.com

Asst. Prof. Dr. Tara Dabbagh

Department of English Language/College of Languages/Salahaddin University /Erbil tara.dabbagh@su.edu.krd

\begin{abstract}
The events surrounding Harper Lee's To Kill a Mockingbird (1960) exemplify the role of race in the determination of judicial outcomes within a divided society. Within this paper, the interaction between race, economic power- or the lack of it-, and social stratification or classification becomes clear as Atticus, the protagonist, seeks justice for a black man, Tom Robinson. The text also touches on the potential for white interests being at the heart of the white men's efforts to help minorities, such as in Atticus' attempt to seek justice for Tom Robinson. The position is that Atticus only seeks to build his name and reputation, as opposed to being truly interested in finding justice for the oppressed. Applying the Critical Race Theory perspective demonstrates the manner in which the social, economic, and historical factors lead to the diminished possibility of positive outcomes for minorities within a system that is based on racial majoritarian beliefs and interests.
\end{abstract}

\footnotetext{
* A Part of an Ma Thesis Entitled (Judicial Racial Discrimination in Harper Lee's To Kill a Mockingbird and John Grishams a Time to Kill).
}

DOI: 10.33193/JALHSS.42.24 


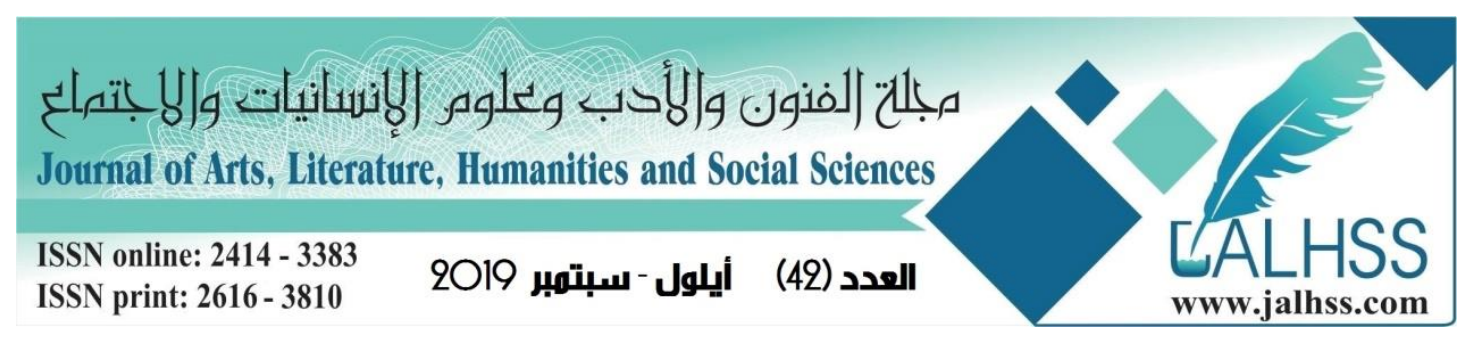

\section{INTRODUCTION}

This paper analyzes To Kill a Mockingbird (1960) against Critical Race Theory through giving the backdrop of the novel and looking into its themes of racial discrimination and attitudes, stereotyping, class divisions, and the resulting injustice. The research shows how the judicial system is worked by these forces.

\section{Backdrop of the Novel}

To Kill a Mockingbird, by Harper Lee (1916-2016), is set in a lazy American town in the 1930's South, Maycomb. The view of the town, even among its inhabitants, is that of it being a slow town where nobody was ever in a particular hurry. The narrator, the young Scout, depicts it as tired stating, "A day was twenty-four hours long but seemed longer. There was no hurry, for there was nowhere to go, nothing to buy and no money to buy it with, nothing to see outside the boundaries of Maycomb County" (Lee, 1960, p. 2). This relatively slow pace is to be expected of any town in the course of the Great Depression, when the majority of the country experienced consistent poverty even as the social context underwent relative progress in the articulation of minority rights- such as through the granting of freedom for black men from slavery. As such, the narrative unfolds within a small town where the most eventful occasion before the main disaster, the trial, wrongful conviction, and ensuing death of the African American Tom Robinson, is the mysterious existence of the Radley family and their house. A mentally disturbed Boo Radley lives with his parents in a solitary house that never seems to have any external activity, with the single occasion when Boo attacks his father creating the most attention.

The slow pace of the town is disrupted by the sudden occurrence of a crime that highlights the otherwise quiet animosity or racial tension existing in the town. The relationship between ethnicity and authority or race and justice forms the core component that perpetuates the events in Harper's To Kill a Mockingbird. Evidence of an unjust legal system characterizes the entire narrative, accentuating the degree to which social sentiment clouds the judgment of the individual and the perceptions that are expressed within the judicial processes. The commencement of the drama that characterizes the entire narrative is the report of the alleged rape of Mayella, a white young woman, by Tom, an African American man, which leads to Atticus, the father of the narrator and protagonist Scout, being appointed to defend the accused man. The decision of the court to convict Tom, despite all evidence indicating his innocence, acts as the central indication of the injustices of a racially divided judicial system towards the minority. The events surrounding this trial and its aftermath lead to the realization of the inability to understand the experiences of the minority without having stood in their shoes to understand them sufficiently. Scout thinks, "Atticus was right. One time he said you never really know a man until you stand in his shoes and walk around in them," (Lee, 1960, p. 201). The dimension, while referring directly to the difficult life of Boo Radley, sufficiently expresses the problem of the white 


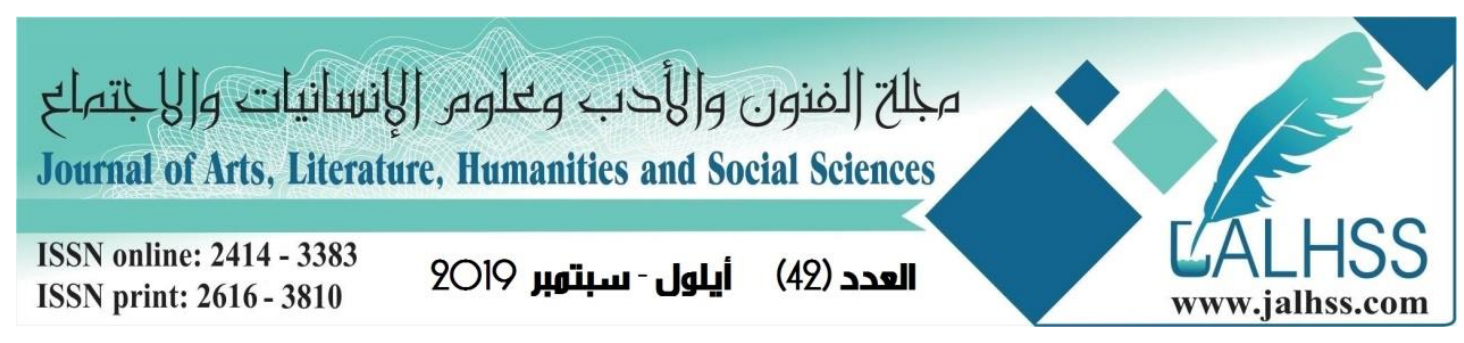

majority in their failure to fully conceptualize the injustices historically evident against the black minority especially within the provisions of the law.

\section{Harper Lee's Portrayal of Prejudice and Racial Discrimination in To Kill a Mockingbird}

Harper Lee makes bold choices in the process of tackling racial discrimination in the deep south. She portrays it as an accepted social convention, and as a hindrance to a rightful application of the law. Lee also hints in her narrative at the intersectionality of race, gender, and class division.

\subsection{Racial Discrimination as a Social Convention}

Lee's choice of characters in her novel is deliberate, outlining issues that manifest in conventional social interaction as well as and emerging events likely to aggravate underlying social tensions. A case in point is Calpurnia's place within the Finch family which becomes particularly conspicuous from the beginning. Although, as a caring maid, she is the mother figure for this family who rules with somewhat of an iron fist, she is still never an equal in society. She deliberately has to change her accent when interacting with the Finch family into that of the whites, with her manner of communication changing while at church with other black people (Lee, 1960, p. 113). Even though Atticus demands that the children accord her the respect she deserves, the sentiments are not constant across other white people in this community. Consequently, it becomes clear that the helpfulness and the important roles of black people in this community may go largely unappreciated solely on the basis of race.

Black people are also shown to be disparaged and harassed by white people. While Ewell, Mayella's father, is busy pursuing supposed justice for his daughter, he is also engaged in abusing Link Deas' black cook Helen, who is Tom's wife. His abuse is never physical but he harasses her to such degrees that she has to change her path. This abuse only ceases when Link Deas interferes with the threat of sending Ewell to jail for it (Lee, 1960, p. 180). The perspective demonstrates the vulnerability that remains for the black people in this society and its prevalence among black women. It would be unthinkable for a white woman to experience the horror that Helen undergoes on a daily basis (Lee, 2010). That nothing happens to Ewell except the threats from Link Deas is further testament of the socially privileged position that white people hold. Compared to the aggressive pursuit of punishment he seeks for Robinson, it is ironic that his behavior should lack any real consequences.

Ewell is not a respected figure in Maycomb. Even before the scandal, Atticus already expresses his disdain for the Ewells, stating that:

the Ewells had been the disgrace of Maycomb for three generations. None of them had done an honest day's work in his recollection. He said that some Christmas, when he was getting rid of the tree, he would take me [Scout] with him and show me [her] where and how they lived. They were people, but they lived like animals (Lee, 1960, p. 57).

Lee (1960) does not shy from elaborating the degree of moral degradation that the Ewell family has exhibited over the generations. In the case of Mayella and Bob 


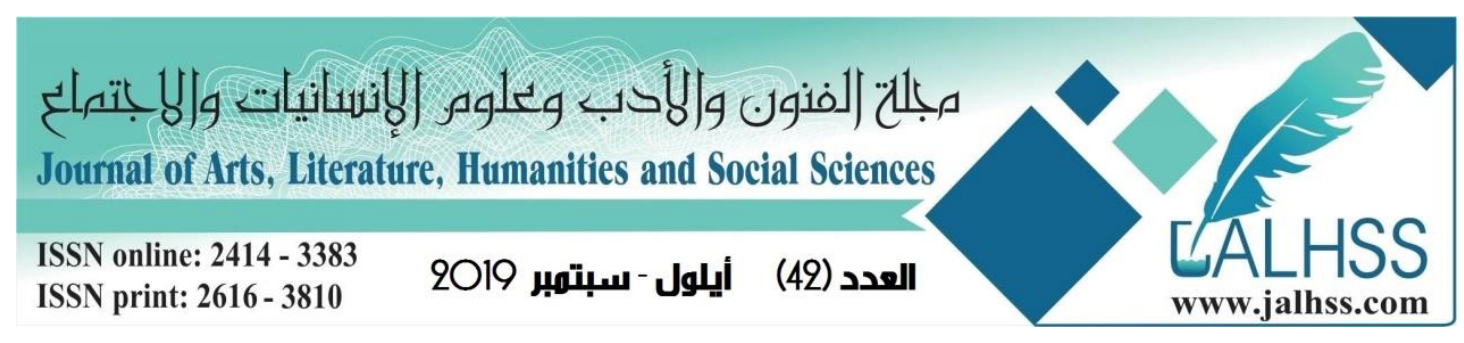

Ewell, their moral rot seems to exceed their typical disinclination to attend school or hold any display of class within the conventional society. A notable premise that manifests in the course of the trial is the undertones suggesting that Mayella and her father are potentially in an incestuous relationship. In Tom Robinson's testimony, he suggests Bob's abuse of his daughter stating, "She reached up an' kissed me 'side of th' face. She says she never kissed a grown man before an' she might as well kiss a nigger. She says what her papa do to her don't count" (Lee, 1960, p. 153). It explains, to some degree, the anger that Bob Ewell shows at finding his daughter in the company of another man. The possibility, as presented to the court, should throw doubt on anything Bob says and his testimony regarding the encounter involving his daughter. It is a complete shred to his character, a factor that should immediately perpetuate a negative view of him within the jury. The implication that he is not only incestuous but also a pedophile should be inherently damaging in a context where all judgment is not reserved for black people; which is clearly not here.

However, once the scandal with Tom Robinson ensues, the entire community seemingly forgets the worthless existence of the Ewells beyond the garbage dump. The focus is entirely on the race of the supposed victim and perpetrator of the crimes within this community, with explicit bitterness stemming from the decision by Atticus to take his appointment as Tom's defending lawyer seriously and not perform it in a merely perfunctory manner as was generally expected and desired. The sentiments are clear in the words of Cecil Jacobs, Scout's classmate and the typical middle-class white child in the story, when he provokes a fight with Scout. "My folks said your daddy was a disgrace that nigger oughta hang from the water-tank!" he says (Lee, 1960, p. 88). Evidently, the people have already made up their minds about the accused man despite the accuser being characteristically prone to trouble, and despite Tom being a fairly decent man with manners befitting any white gentleman. Race trumps all the other potential influencers or factors of judgments of personality, with the lack of class or the notoriety exhibited by the Ewells no longer manifesting as relevant in this context. That Bob may have continuously abused Mayella after the death of her mother loses significance in the eyes of the jury. Moreover, Atticus and his children become targets of antagonistic feelings which manifest within the community because of Atticus' defending a black man. To the majority of the people, evidently, the Ewells' whiteness trumps all other factors as an influence on their thinking.

At this point, considering the perspectives of Delgado and Stefancic (2000) on the capacity and limitations of the law becomes crucial. The authors posit that formal equal opportunity laws and regulations are insufficient to overcome the ingrained racism within the landscape of conventional culture. They can "remedy only the more extreme and shocking forms of injustice, the ones that do stand out. It can do little about the business-as-usual forms of racism that people of color confront every day" (Delgado \& Stefancic, 2000, p. xvi). There is no way to prevent Cecil's attack on Scout, as there are no provisions in the law against holding discriminative opinions 


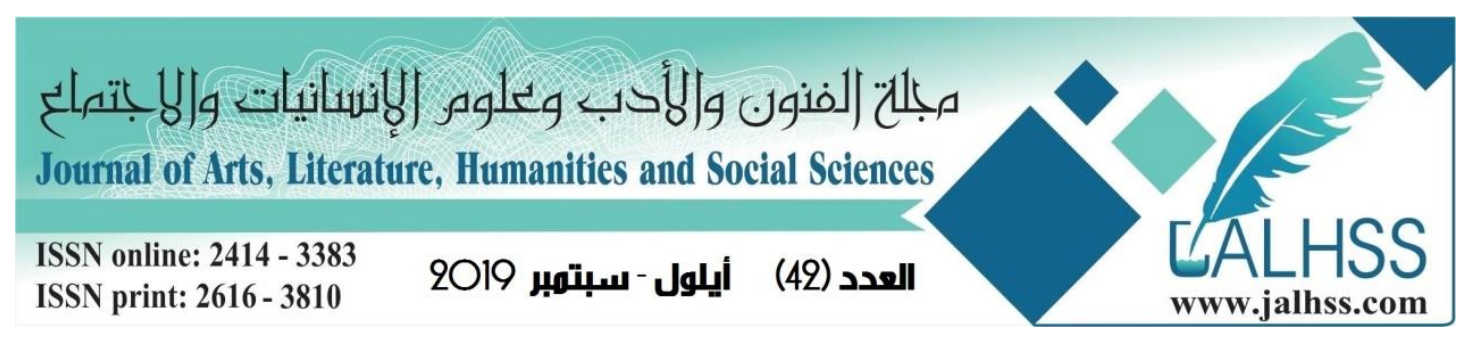

beyond the justice system. Consequently, the perceptions held by the members of the community prove to be far beyond the provisions of the justice system, rendering it crippled in the prevention of harmful actions such as accusatory notions and the verbal insult imposed on this minority and on those who stand by them.

Perhaps in addressing these inconsistencies it would be prudent to refer to the entire spectrum of issues that characterized the historical context of this community. Lee expresses one of the core fears that characterized the dominantly white South: the sexual interaction between black men and white females (Delgado \& Stefancic, 2017). Indications are that the decision from Brown v The Board of Education (1954) ${ }^{\dagger}$ was the exacerbation of fears on the unconventional mixing between black people and white people within multiple social contexts. The widespread belief was that in pursuing their civil rights, the black people in this community simply sought to accomplish the opportunity to engage in sexual intercourse with white people; especially white women (Lee, 2010, p. 50). Viewing this notion from a contemporary perspective could appear rather absurd, but it formed a core aspect of the fight against school integration in the course of the twentieth century. Consequently, Tom Robinson's violation may not have been momentous due to its being a crime, but due to the underlying affirmation of the greatest fears that the community held regarding interactions with black people.

The inculcation of fear and the presence of socially constructed "whiteness" remain socially significant conceptions even for the modern reader of this text. Whiteness, as a social construction, leads to the creation of white supremacy and the consequent perception that being of any other race implies inferiority (Burton, et al., 2010). With the inferiority comes fear and isolation, with interactions across races being hindered by the barriers to conventional social fluidity. Despite knowing he was doing nothing wrong in his encounter with Mayella, Tom chose to run. He can offer no other explanation for his behavior except that he is black, "Mr. Finch, if you was a nigger like me, you'd be scared, too" (Lee, 1960, p. 154). Fear is often a defining aspect in the lives of the minority or the marginalized, especially among black people and women. Similarly, ethical fear forms a crucial component of this racist existence; implying the fear of being feared (Peller, 1995, p. 335). This position by Peller refers to the fact that minorities are afraid of interactions that put them in a position to elicit fear, much like a black person avoiding entering a lonely street with a white person so as not to scare the latter or face accusations like attempted robbery. The perspective explains the decision by Tom to run, convinced that there could be no positive reaction to his presence at the Ewells' house.

The hatred for the black people in this community is evident, elaborated in the individual opinions and perspectives of Braxton Underwood. Braxton is the editor of Maycomb's paper, prone to drinking cherry but a close friend to Atticus. Atticus

\footnotetext{
${ }^{\dagger}$ A landmark ruling in the US, abolishing racial segregation in public schools and representing one of the crucial steps in the civil rights movement
}

DOI: 10.33193/JALHSS.42.24 


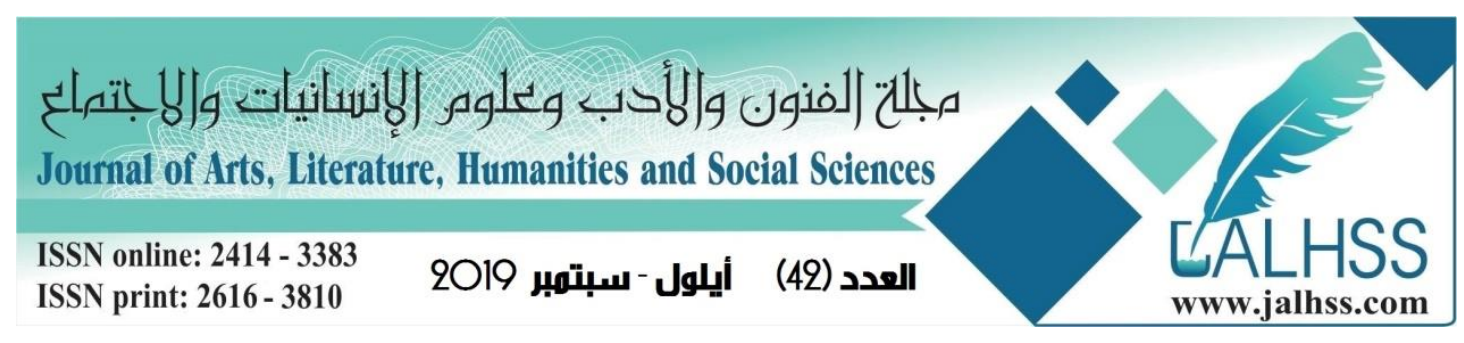

elaborates, "You know, it's a funny thing about Braxton...He despises Negroes, won't have one near him" (Lee, 1960, p. 133). This perspective accentuates the nature of the society within which this narrative unfolds. There is a grudging acceptance of people that are racist, perhaps in the manner condemned by the CRT on the normalcy of racist sentiment (Burton, et al., 2010). Their expression of dislike for the negroes is not a matter to be hidden, which elevates the potential for injustice within this society and its justice systems.

There seems to be general consensus that the voices of the black people should remain unheard, even when they are aware of the events that unfold around them. This is particularly important, considering that they are often the victims of these events as opposed to the perpetrators. According to the Critical Race theorists, moral analyses are always situational such that truths are only relevant to the person facing a predicament during that moment in history (Billings \& Tate-IV, 1995). Consequently, that the black people in the community are not part of their own truth is disconcerting. Atticus expresses as much, telling Aunt Alexandra that "I don't know of any law that says they can't talk. Maybe if we didn't give them so much to talk about they'd be quiet" (Lee, 1960, p. 133). As such, the worry by Alexandra that Calpurnia and other black people speak among themselves is far from unfounded. However, it is irrational that she expects them to remain silent on the hostility they face from the white people in this community, despite this hostility having a direct influence on their lives and fates.

Therefore, Maycomb's conviction that the black people should be silent, or unheard, inherently draws from underlying convictions of their (the black people) inferiority to the white community in Maycomb. The hostility that erupts following the involvement of Atticus in the trial is unharnessed, with Atticus expressing it as previously rational people suddenly going stark raving mad the moment anything involving a black person emerges (Lee, 1960, p. 96). The madness is clear in the sentiments expressed by multiple people in the area, such as in labeling Atticus a "nigger-lover" despite no clear elaboration of what is wrong with being this type of person. Perhaps Atticus' explanation to Scout best illustrates the meaningless nature of the term, while also expounding the deep-seated sentiments and derogation that is associated with its use. He explains:

Scout," ... "nigger-lover is just one of those terms that don't mean anything-like snot-nose. It's hard to explain - ignorant, trashy people use it when they think somebody's favoring negroes over and above themselves. It's slipped into usage with some people like ourselves, when they want a common, ugly term to label somebody (Lee, 1960, p. 108).

Essentially, derogatory terms such as these are part of the social construction of racism and the effort to sustain white superiority within this context. The CRT emphasizes this social construction, with Delgado and Stefancic's perspective deeming it as one of the main reasons that racism persists in America over decades despite laws to eliminate the phenomenon (Irby, et al., 2013, p. 104). Race and races are products of social relations and people invent and manipulate specific titles 


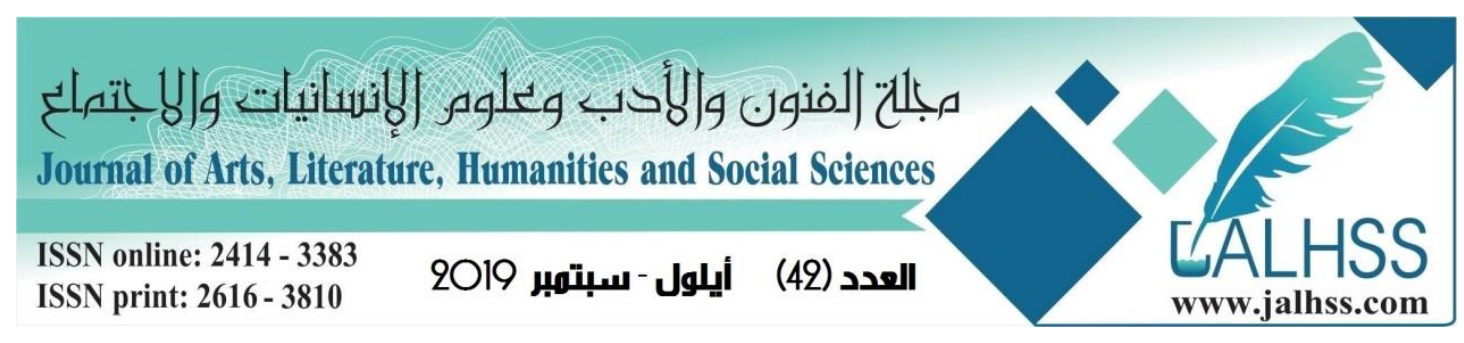

according to context and the degree to which it suits them (Delgado \& Stefancic, 2017 , p. 8). As such, this society has long managed to convey the view of the negro as someone undeserving of respect or love, even where justification for such negative treatment is lacking. It explains the potential for unjust treatment under the law and the failure of the system to adequately protect their welfare due to the influences of social conventions.

\subsection{The Application of the Law}

The predicament of Tom Robinson in being accused of the rape of a white woman accentuates the rather complicated intersectionality that manifests in this context. The perceptions towards Tom are not entirely the result of his race, but also due to the position or work he holds within this small community. He is poor and uneducated, with his status affording him only the most menial of tasks in picking cotton as in the slavery days. Nevertheless, it is possible that race plays a larger role than class and wealth in the determination of the social status within Maycomb. Indications from the CRT are that factors beyond the more perceptible issues of race and gender may be crucial determinants of social outcomes (Gillborn, 2015). Race, however, remains the most obvious in the overall decisions surrounding society and the court in Maycomb. Towards a critical analysis of race, this story by Harper Lee invites the reader to question: how are the crimes in this community perceived? How is the reaction to crimes by white people and black people in the community different? Evidence from the CRT is that the American society boxes people into physical attributes and culture as a matter of convenience and habit (Delgado \& Stefancic, 2017, p. 78). As such, it is predictable that the society within which the narrative unfolds unwittingly classifies the intensity of crimes and the resulting punishment within the same social boxes.

Indeed, it is the context of justice that ultimately highlights the racial discrimination that is prevalent in this community, even before the trial of Tom. Lee's narrative borrows from multiple characters to accentuate the differences in perception and perspective towards crime that are part of the dominant society thoughts. Boo, for instance, never goes to jail on his first attack against his father despite the obvious nature of the crime and his possible mental instability (Lee, 2010). His fate is not an effect of the preference for a more amicable solution for his challenges, but it is propelled by the disinclination towards treating a white man like a black person. The sheriff "hadn't the heart to put him in jail alongside Negroes, so Boo was locked in the courthouse basement" (Lee, 1960, p. 58). Likewise, when Boo kills Ewell to prevent him from hurting Atticus' children Scout and Jem in retaliation for their father defending Tom, he is again spared imprisonment by claiming that Ewell accidentally tripped and met his death. Jail, therefore, is for the black community, not necessarily the worst criminals in the society. Their identity has already rendered them deserving of the position despite the possibility of their innocence. The evidence of white supremacy in the efforts to keep Boo both from jail and the mental institution 


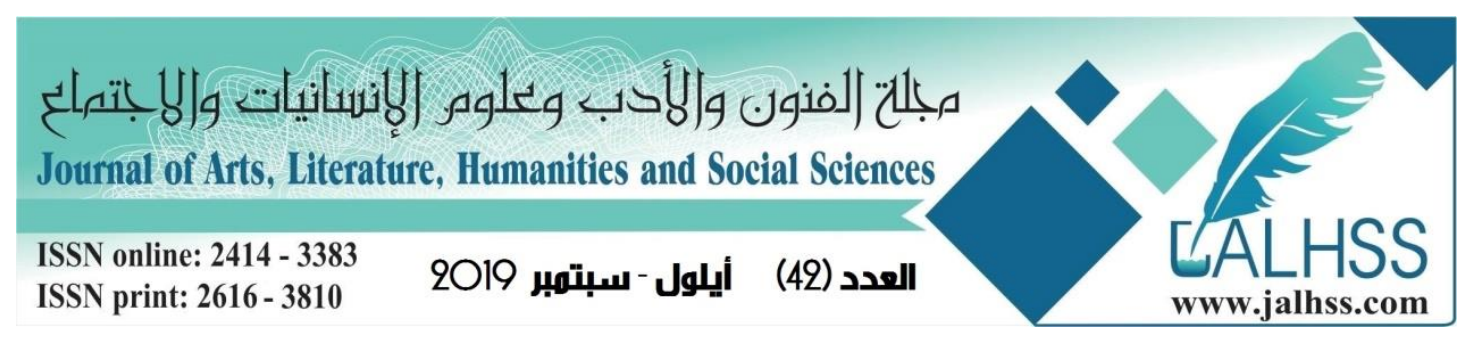

further perpetuates understanding from the critical race theory lens of the differences in the system that emanate from race as a part of identity.

As such, comparison in the behaviors and outcomes between the actions of Boo Radley, Bob Ewell, and Tom Robinson provides a basis from which the shortcomings of the treatment towards Robinson is entirely motivated by race. The whiteness of Boo and Bob transcends all the other factors of human mortality that should determine the value of man and the perceptions the community has towards him. This reflects the views of Harris (1993) in justifying CRT regarding whiteness and property.

He argues:

Even after the period of conquest and colonization of the New World and the abolition of slavery, whiteness was the predicate for attaining a host of societal privileges, in both public and private spheres. Whiteness determined whether one could vote, travel freely, attend schools, obtain work, and indeed, defined the structure of social relations along the entire spectrum of interactions between the individual and society. Whiteness then became status, a form of racialized privilege ratified in law. After the dismantling of legalized race segregation, whiteness took on the character of property in the modem sense in that relative white privilege was legitimated as the status quo (Harris, 1993, p. 1745).

As such, the interests of the white people continue prevailing in the context of this narrative. Boo escapes going to jail and is instead locked in the basement of the courtroom, simply because it would be deemed inappropriate for him to mix with the black people in the jail room (Lee, 1960). At the same time, Bob Ewell harasses a black woman because the chances of his facing any prosecution are minimal. Most scholars in CRT have frequently alluded to the latter intersectionality, reflecting the combination of the disadvantages stemming from race and gender in the perpetuation of the challenges the black woman experiences (Delgado \& Stefancic, 2017). In accentuating this perspective, the theory simultaneously addresses issues presenting for the minority in a manner that an exclusive focus on racial prejudice would potentially overlook.

On the other hand, when the poor but white Mayella Ewell accuses Tom Robinson, an African American, of rape, almost every white person is immediately inclined to believe and support her. The fact that the jury has to pick between the word of Tom Robinson and that of Mayella Ewell already demonstrates the disadvantaged position for the black man within the system. Atticus elaborates, "It couldn't be worse, Jack. The only thing we've got is a black man's word against the Ewells'. The evidence boils down to you-did-I-didn't. The jury couldn't possibly be expected to take Tom Robinson's word against the Ewells" (Lee, 1960, p. 97). The fate of Mr. Robinson seems sealed by the jury even before the court sessions begin.

The CRT grew from a critique of Critical Legal Studies (CLS) and its attempt to premise a prescriptive analysis of law and discrimination. According to the CRT, CLS fails in the presentation of consent as a component in racism- such that racism occurs by consent (Crenshaw, 1988, p. 1357). However, it is clear that black people do not exist in their oppressed states by their choosing but through coercion beyond their 


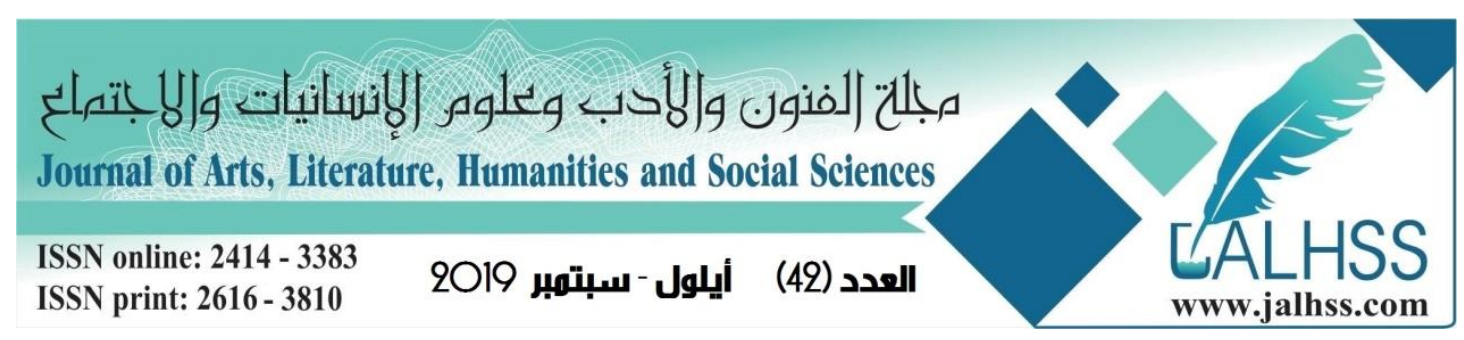

moment to moment existence (Gotanda \& Peller, 1995). This coercion further explains the conviction by Tom Robinson that, in his compromising position with Mayella, his easiest alternative is to flee as opposed to explaining himself. As he explains to Finch, he would also have fled from fear had he been a black man (Lee, 1960, p. 154). A white man in the same position may have elected to stay and explain that he was only assisting the woman. However, the constancy of white supremacy in this society and the disdain constantly expressed towards the black people makes an opportunity such as this impossible for Tom. Instead, he has assimilated to the need to preserve his life regardless of his innocence (Lee, 2010).

The critical race theory offers a different perspective of white supremacy from the conventional definition. Under this theory, it refers to a system in which ideas of white superiority are widespread and there is acceptance of the non-white subordination (Irby, et al., 2013, p. 1021). As such, Lee's depiction of the general attitude of this society exhibits the widespread actions that subjugate the minority regardless of their intention. Further evidence of the influence of white supremacy manifests in the controversial nature of the reception of the testimony by Tom Robinson. The prosecutor and the audience seem appalled that Tom Robinson feels courageous enough to say he felt sorry for Mayella. "You felt sorry for her, you felt sorry for her?' Mr. Gilmer seemed ready to rise to the ceiling. The witness realized his mistake and shifted uncomfortably in the chair. But the damage was done. Below us, nobody liked Tom Robinson's answer" (Lee, 1960, p. 155). The comprehensive view seems to be that the African Americans in this community should be so poor and unhappy they could not feel sorry for the white folk. That a black man should suggest otherwise seems not only impossible, but also unacceptable to the society convinced of their supremacy over the black minority.

Even then, there seems to be individuals convinced of the value of ensuring justice in a colorblind form. Atticus, perhaps, best represents this pursuit of justice for the minority in the manner an equal society would guarantee. To a large degree, the voluntary engagement of Atticus in this case provides the purpose of the critical race theorists in their reform of the approach of the law towards minority issues. Derrick Bell elaborates this CRT view where:

Its goal is to review those issues in all their political and economic dimensions, and from that vantage point enable lawyers and lay people to determine where we might go from here. The goal for us, as it was for all those back to the slavery era who labored and sacrificed for freedom, was not to guarantee an end to racism, but to work forcefully toward that end. (Bell, 1992, p. 14)

Atticus recognizes the economic and political shortcomings that confront the black man within this society that diminish his potential for getting justice. He states the same to his brother, who is referred to by Scout as Uncle Jack, where the futility of Robinson's testimony exclusively is clear as a basis for pursuing his freedom. The blackness in the man has, seemingly, already sealed his fate in the eyes of society and the justice system. Atticus, nevertheless, is determined to perform all the legal steps in 


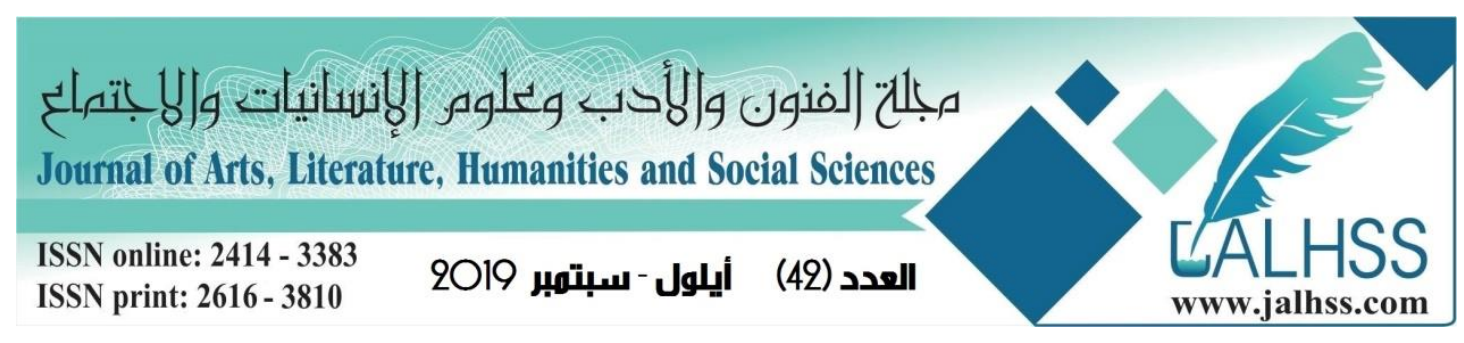

the pursuit of justice for the black man despite recognizing the difficulty of the case. In fact, it appears he would rather not have caught the case. He elaborates this position in his conversation with Uncle Jack stating, "You know, I'd hoped to get through life without a case of this kind, but John Taylor pointed at me and said, 'You're It."' (Lee, 1960, p. 90). As such, while the challenges are clear, Atticus is willing to confront them in defense of the man.

Atticus' defense of the black man offers the reader insight into the possibility of people unwilling to succumb to the discrimination in society and pursue the rights of the oppressed. Despite only being appointed by the court, Atticus actually aimed to defend Tom (Lee, 1960, p. 136). The implication is that any other person would have executed the role half-heartedly without the zeal Atticus puts into it. His intention is to see the expected justice that should prevail within an equal society. Race, in the CRT, is socially constructed. As such, it can be adopted and discarded by the society at their convenience (Delgado \& Stefancic, 2017, p. 8). Atticus seems to rely on the possibility of evidence presented in favor of the accused man compelling the community towards discarding their perceptions of race and racism and embracing the equality that the court system is intended to perpetuate.

Atticus' commitment to the plight of Tom Robinson is evident in his eventual appeal to the principles of equality that are fundamental to the foundation of the nation. $\mathrm{He}$ elaborates:

Thomas Jefferson once said that all men are created equal, a phrase that the Yankees and the distaff side of the Executive branch in Washington are fond of hurling at us... Our courts have their faults, as does any human institution, but in this country our courts are the great levelers, and in our courts all men are created equal (Lee, 1960, p. 159).

As such, Atticus calls to question both the capacity of the justice system as well as social conventions to ensure equality in the administration of justice for the black people in the society. Such premises, the CRT provides, are illustrative of the belief that reforms to the legal system and updates such as introductions of change in the civil rights movement are sufficient to guarantee equality for minorities (Bell, 1980, p. 522). However, the daily experiences and prejudices against black people, or other minorities, prove the contrary (Delgado \& Stefancic, 2000). In fact, without access to the narrative that accentuates the experiences of the black people from their perspective, racist white people are unlikely to see any fault in their practices. Consequently, racism is likely to persist in the society as the legal system cannot guarantee the delivery of equal treatment for minority populations; both within the justice system and in the social setting (Macaluso \& Macaluso, 2018, p. 113). Such failure, therefore, brings into doubt the authenticity and viability of the appeal to the equality principle in the closing argument as delivered by Atticus.

Perhaps most relevant to the theory are the motivations for Atticus agreeing to the defense of the black man. Critical Race Theory accentuates the possibility that reforms or actions by white people that seem to favor African Americans are often in 


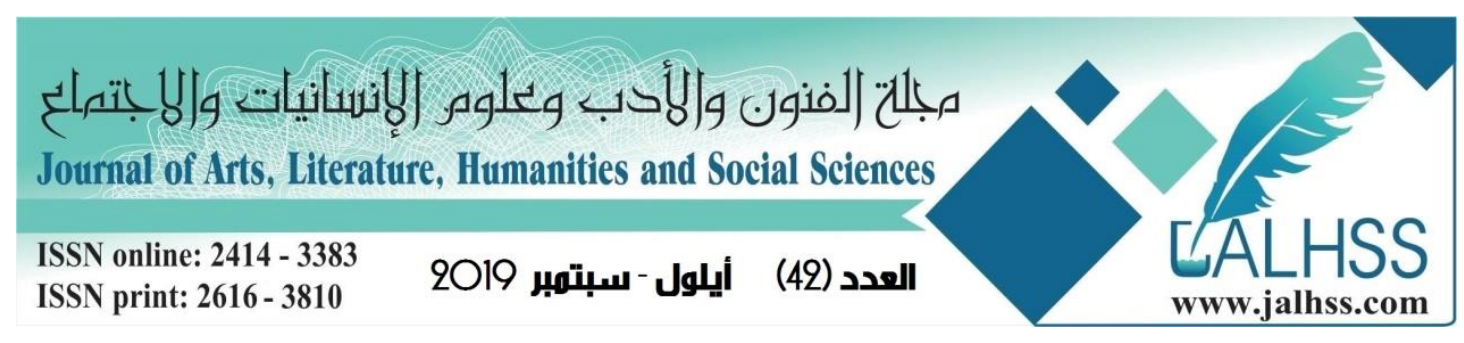

the interests of the white leadership. For instance, reforms during the civil rights era can be associated with the foreign interests that the United States had at this time. This was such as the international agenda against Haitians colonization in the 1930s, and post-war searches for support in the third world in the context of the Cold War (Burton, et al., 2010). Therefore, it might be argued that the actions by Atticus are less from his sense of philanthropy and more based on his own self-interests. Atticus tells his brother he has no idea how he could face his children if he chose otherwise (Lee, 1960, p. 90). There is a clear interest on his part, therefore, to appear as a reasonable and unbiased man within the social setting in which he exists, especially in the eyes of his children. Consequently, Atticus might be perceived to be lacking true interest in the fate of the man falsely accused of rape beyond his concern for his parental and social image.

The subject of Harper Lee's Atticus has confronted the contemporary scholar, especially in the aftermath of the critical race theory. The focus of this theory is on ensuring that the minority has the chance to narrate history from their perspective, in a manner that the majority white narrative is unable to comprehend (Delgado \& Stefancic, 2017, p. 10). Essentially, the theory argues for the establishment of a system where those that have truly been in the shoes of the minority are the source of their accounts (Bell, 1992). This perspective seems to be part of Atticus' views on the minority and the difficulty of their experiences. He tells Scout of the need to know a man through truly walking in his shoes (Lee, 1960, p. 201). However, through the entire narrative, there is no clear effort by Atticus to actually walk in the shoes of the man he so seeks to defend. Instead, scholars argue, Atticus focuses the entire narrative on his effort to appear an honorable man, in society's eyes and in the eyes of his children (Zwick, 2010, p. 1350).

The fault may be in Harper Lee's framing of the narrative, focusing entirely on the experience of Atticus Finch in the course of the trial as opposed to the man that eventually loses his life for a crime he did not commit. The audience knows everything there is to know about Finch, his children, and his beliefs. But what is there to know about Tom Robinson beyond the bare minimum? Nobody can empathize with Robinson beyond his being a man on trial as there is no effort to explain his background or life. There are details he shares with the court, but these are only the necessary details one would expect in the conventional proceeding.

On the other hand, the reader has a clear insight on the kind of man Bob Ewell is and his treatment of the daughter, Mayella. At the same time, the life of Atticus is clear, as is that of his children and relatives. However, Tom Robinson remains a shadow in his own narrative (Zwick, 2010, p. 1356). This is in the same manner the black population in the United States has remained in history's shadow, despite the reforms to the justice system apparently being crafted to address the injustices historically encountered by this population (Bell, 1992, p. 132). His feelings or thoughts remain an irrelevant part of the events that unfold beyond his accusation by the Ewell's, with the entire narrative unfolding from Finch's perspective. 


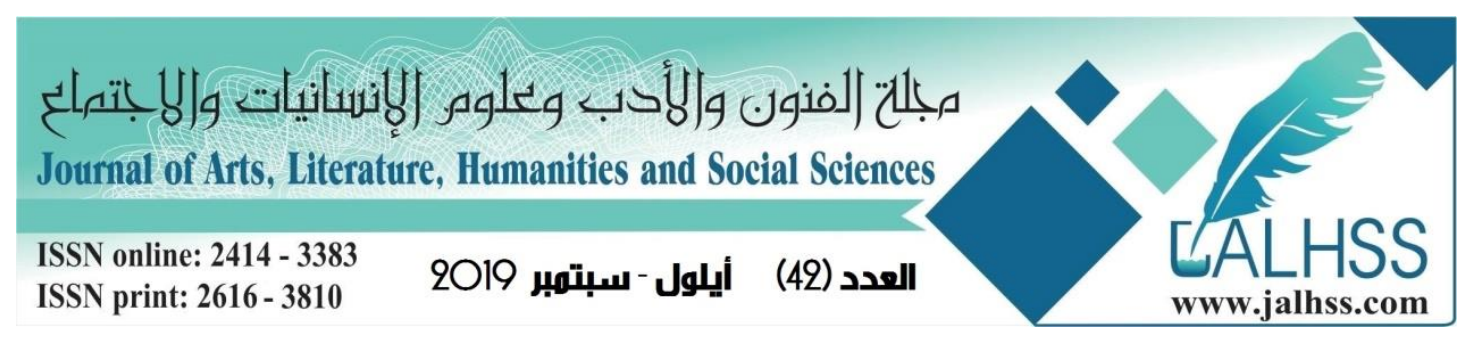

Lee seems to have chosen the approach deliberately, confirmed in a later book, Go Set a Watchman. The reception of the book involves, in part, horror by the reader as they encounter a version of Atticus that is suddenly seemingly racist and argues that the black people in the South in the 1950s are still not prepared for comprehensive civil rights (Lee, 2015, p. 119). However, it is possible that Atticus might be thinking that these rights need to be introduced to the black community gradually to enable and empower them to handle these rights wisely. The horror is best reflected from Scout's perspective, who has idolized her father her entire life for his seemingly strong stance against racism or discrimination. Nevertheless, it does induce the need for the reader to reflect on the ideas sowed by Atticus in To Kill a Mockingbird and the need for independent conclusions regarding his ideas and position. When the world has the opportunity to see the world in Maycomb beyond the story of Atticus Finch and his heroism, it becomes clear that the dedication to the fate of the black man may not be as unselfish as previously portrayed by the white-based narrative.

Admittedly, most of the effort seems to be more about the portrayal of Atticus as an honorable man and less about the depiction of Tom Robinson as the same. In the court, the judge elaborates to Mayella, "That's just Mr. Finch's way," he told Mayella. "We've done business in this court for years and years, and Mr. Finch is always courteous to everybody. He's not trying to mock you, he's trying to be polite. That's just his way" (Lee, 1960, p. 147). Perhaps, the idea of Robinson- a black manas an honorable man is inconceivable. To expect that Atticus recognizes the position Robinson is in, therefore, is illogical in this case. In fact, arguing that he pursues the case entirely for his (Atticus') sake would be justified. Atticus, therefore, seems to be doing all this for his own selfish motives and personal build of image.

Harper Lee's novel, to some degree, becomes a white savior narrative as opposed to the accentuation of the experiences of a black man within a racially discriminative society. In this position, the reader can observe the urgency of the critical race theorists for counternarratives that are told from the views of the black man to accentuate their experiences in such incidents. Atticus becomes a literary hero and the narrative's plot becomes a tool for the creation of the proof of his morality (Macaluso $\&$ Macaluso, 2018, p. 110). Tom's portrayal as a character of color, relative to the portrayal of Atticus, does little to change the thinking of white people on racism. In fact, Atticus seems to accept this discriminative form of thought as he refrains from condemning Cunningham in his explanation to Scout after the lynching attempt:

I thought Mr. Cunningham was a friend of ours. You told me a long time ago he was."..."He still is."..."But last night he wanted to hurt you." ...Atticus placed his fork beside his knife and pushed his plate aside. "Mr. Cunningham's basically a good man," he said, "he just has his blind spots along with the rest of us (Lee, 1960, p. 83).

\footnotetext{
¥ The book, Go Set a Watchman, was actually written in 1957 before To Kill a Mockingbird. However, it was perceived as not ready for publication at that point, instead acting as the basis for the inspiration of the more famous novel, To Kill a Mockingbird. It was released in 2015.
} 


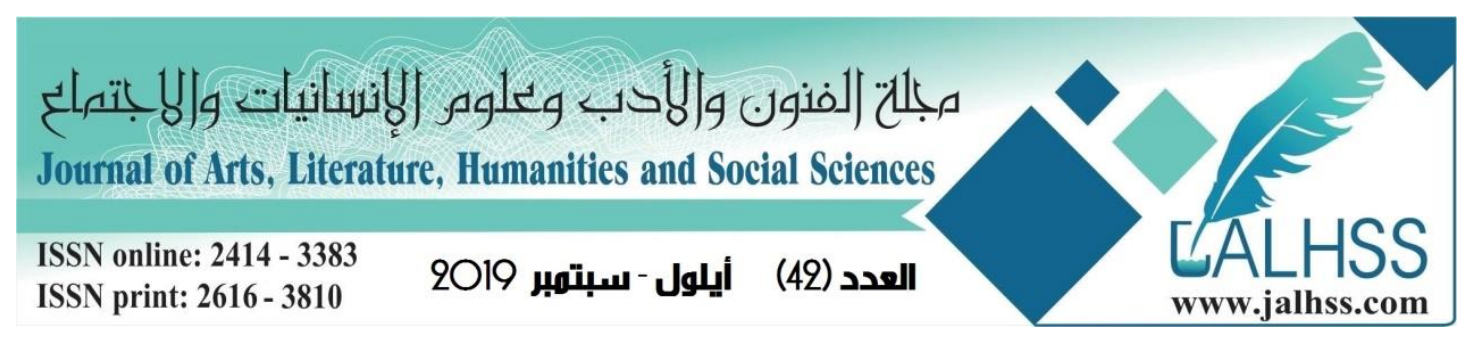

The reluctance suggests his unwillingness to extend his opinions to exerting overt influence on the racist thoughts of society. He seems convinced on the need for an equitable society and, even though he is doubtful, of the capacity of society to make change despite their underlying negative sentiments. He downplays the significance of the event to Scout's suggestible mind, ostensibly revealing the criticism of the critical race theory against the inability of society's consistent racism to articulate adequately the suffering black people and other minorities experience (Macaluso \& Macaluso, 2018, p. 111). Cunningham clearly meant to hurt Tom for the accusation of having raped a white woman. Atticus, even though he seems inclined to fight for the fate of the black people, represented by Tom Robinson, it is clear he chooses these fights only in contexts where the possibility of winning, albeit meagre, still exists. This cannot be justified by that it will come to nothing if he unanimously opposes white nationalism. Atticus is simply playing the game for as long as it suits his interest, ensuring to preserve his personal position in the racist community by not directly antagonizing people like Cunningham, but also appearing as heroic in defending the weak.

The perspective of Atticus' motivations, therefore, details the faults that exist in current and past efforts at reforms in the justice system on the basis of race. In fact, interest convergence is perceptible in major decisions previously thought to have been in favor of the black population such as in the ruling in Brown where segregation in public schools was abolished. Such reforms advance the interests of the white population as opposed to perpetuating victories for the black man. Bell (1980) best articulates this dimension of interest convergence in the initial challenges to law reforms under the CRT:

The interest of blacks in achieving racial equality will be accommodated only when it converges with the interests of whites. However, the fourteenth amendment, standing alone, will not authorize a judicial remedy providing effective racial equality for blacks where the remedy sought threatens the superior societal status of middle- and upper-class whites (Bell, 1980, p. 523)

Similarly, while Atticus seemingly indulges in the pursuit of justice for Robinson, his efforts in no way disrupt the civil and social setup within this southern society. It is noticeable that Atticus, while believing Robinson, fails to express this opinion to the jury and only mumbles it to himself. While delivering his closing argument in court with the appeal for the jury to exercise their best judgment in the name of God, he seems to be speaking more to himself than to them when he says, "In the name of God, believe him" (Lee, 1960, p. 160). This, while seemingly an oversight, is evidence of his unwillingness to hoist on the jury an opinion contrary to their wellestablished prejudice against the black people in their community. While seemingly bold in his defense, Atticus remains, nonetheless, unwilling to upset the status quo beyond the point that favors his social standing as a bold and indiscriminative man.

While Atticus' unwillingness to offset the racist perceptions within this society may be difficult to perceive, the rest of society's discrimination on racial grounds is 


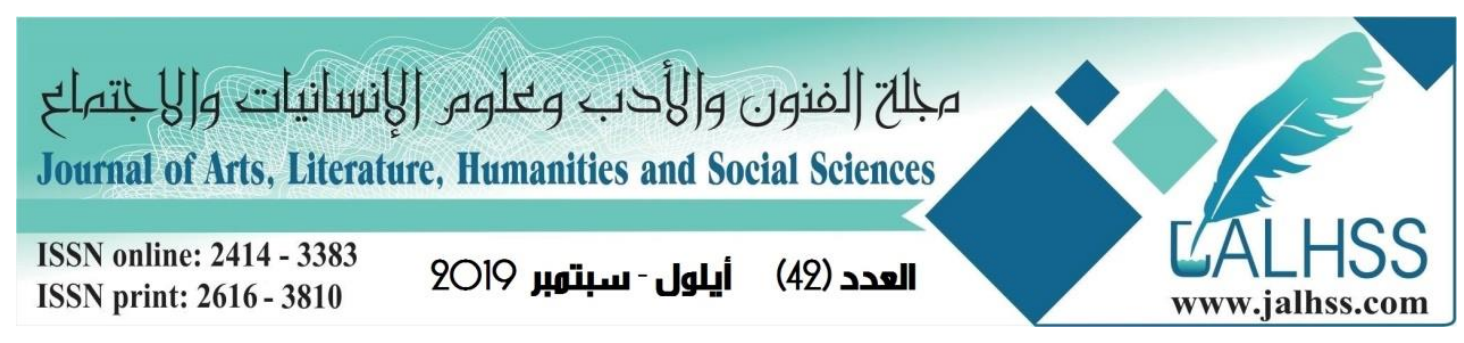

evident. From the beginning, when Atticus accepts the case, it is clear that everyone would rather he discards the assignment as opposed to willingly defending a black man. As such, the Negroes in this narrative are the criminals regardless of the utilities they provide of exhibit. Tom Robinson's fate is sealed from the moment of his accusation despite the strength of Atticus' argument. It does not matter that Tom is innocent and only wants to help Mayella as he felt sorry for her (Lee, 1960, p. 149). His condemnation despite his innocence is as sinful as killing a mockingbird as all they ever do is provide music and bring joy to the world (Lee, 1960, p. 96). When it comes to the innocent black people in this community, the perception of $\sin$ is overlooked as people commit to ensuring the worst possible outcome for the man. That they are willing to lynch him and nearly succeed, save for the timely interference by Scout, attests to the persistence of social injustice in this community despite the existence of a justice system that supposedly protects the administration of equal rights. People want to take the law into their own hands. They feel there is no need to allow a black man the right of legal procedure and punish him on the spot.

As such, typical to the views of the CRT, the events in this narrative attest to the limitations to the legal system in ensuring equality and justice for the minority or the oppressed. This concept is further elaborated by Greenbalt's Invisible Bullets in the course of accentuating the process of subversion and containment. In this text, power is never perfectly monolithic and has the capacity to encounter materials that threaten some of its functions (Greenbalt, 1988, p. 51). The acknowledgement of the limitations to legal power or reform leads to the recommendation for vigilance, whereby its exercise may compel the subversion of personal values to which one has previously subscribed (Lee, 2010, p. 53). The vigilance is perceptible in Atticus' willingness to overlook justice in the courts in covering for the eventual murder of Bob Ewell after the unjust ruling against Robinson.

The outcome of this narrative leaves open the fact that justice fails despite the presentation of evidence within the legal system and the adherence to the law. Social convictions of the negro as a criminal overrule evidence and the function of the court. Provisions under the CRT are that the reforms to justice limited to laws are inadequate without articulating the true experiences of the oppressed (Peller, 1995). The inadequacy is clear in this narrative, with the fate of the innocent Tom Robinson sealed by the social verdict against the negro as opposed to the objective review of evidence. As Lee (2010) elaborates in the review of her book, in the secret courts of men's hearts, Tom Robinson never stood a chance. All the people in this context can do is improvise means of justice that are unpronounced and silent, such as the murder of Bob Ewell and its ruling as an accident (Lee, 1960). Nevertheless, such efforts, drawing from disillusionment with the adequacy of the legal system, remain insufficient to accomplish the challenge to the status quo and the consequent accomplishment of equality within an otherwise discriminative system. 


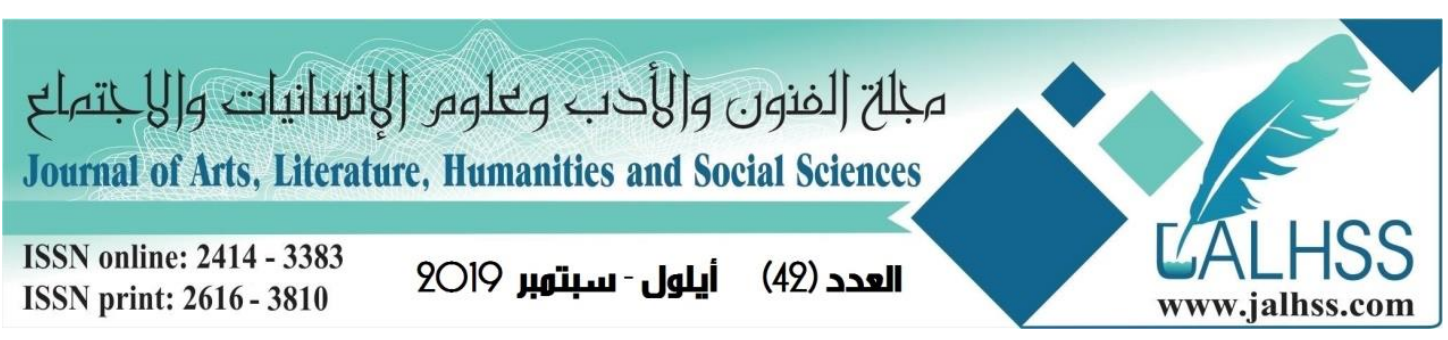

\subsection{Intersectionality of Race, Gender, and Class Division}

Challenges to ahistoricism in CRT insist on the consideration of the social, economic, and historical contexts of racism (Matsuda, et al., 1993). Intersectionality manifests within this context, with the premise that differences in individual characteristics such as gender have the capacity to influence the individual experiences of the members of a seemingly similar group (Maisuria, 2012, p. 84). As people are simultaneously members of multiple groups, the intersectionality makes particular people more vulnerable to specific forms of bias than others (Crenshaw, 1988, p. 3).

In agreement with CRT, analyzing the case of Tom Robinson and the effort to find justice requires the consideration for the historical, social, and economic contexts of the occurrences and pursuits of justice. Lee's novel justifies the stance of CRT in opposition to the adoption of the ahistorical approach to understanding race. In her book, although race remains a dominant factor in the determination of the speed and comprehensiveness of justice, the presence of additional factors like class and gender also mediates this process. If Tom Robinson, for instance, had been accused by a black woman, the process would probably not have been as against him- as demonstrated by perceptions towards women like his widow. The testimony of Bob Ewell also appears more significant than Mayella's, implying the role of gender in determining the speed at which the wheels of justice turn. Bob Ewell is also later threatened with prosecution, a feature that never takes place against the better placed Boo Radley on the social ladder despite his engagement in attempted murder and, later, in actual murder.

The premise, consequently, brings into perspective the intersectionality of race and class within the society at Maycomb and its influence on the lifestyles of individuals as well as their outcomes with the justice system. Atticus communicates this need to differentiate the implications of poverty on the people involved in this case. He speaks of Mayella, stating, "She is the victim of cruel poverty and ignorance, but I cannot pity her: she is white. She knew full well the enormity of her offense, but because her desires were stronger than the code she was breaking, she persisted in breaking it," (Lee, 1960, p. 156). Atticus' perspective includes the variance in Mayella's experiences of poverty and ignorance from those of the black people. She understands the difference expected of her interactions, and that she would expose herself to the violation of social codes preventing sexual coupling with black people in the community is undeserving of pity. Race, in this case, makes Atticus' case against pitying Mayella, implying the clear difference in perceptions expected among poor people of color and their white counterparts. While Atticus may openly advocate equality among all, he seems to support the maintenance of the sexual boundaries between men and women of different races.

Nevertheless, perhaps the most evident articulation of intersectionality in the narrative stems from the portrayal of the black woman. Calpurnia emerges as a black woman with strong convictions as well as the realization of the limits of her capacities. While she is in control of the children within the Finch household, it is clear that she is still 


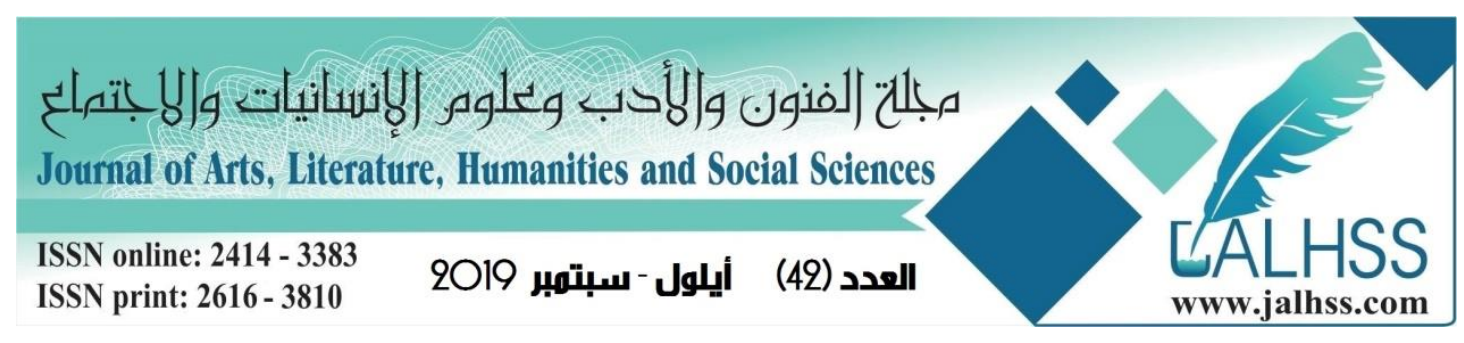

subject to ridicule and disrespect from others like Aunt Alexandra (Lee, 1960). Intersectionality as it relates to the black woman is of particular interest in CRT (Maisuria, 2012), which makes it all the more intriguing the presentation of this character by Harper Lee. While Atticus and his children treat her like a family member, the sentiments of the rest of society come to light with the arrival of Aunt Alexandra. She vehemently protests Scout's intention to visit her at home and demands that Atticus releases Calpurnia in the interest of his growing daughter (Lee, 1960, p. 115). Such antagonism is unnecessary but an indication of the distortions of fact and defensive attitudes characteristically associated with dealing with the situation of the black woman (Gillborn, 2015, p. 161).

Hancock (2010) elaborates the shortcomings in the treatment of the black woman relative to the progress in society and the conventional points of failure. According to an account from the 1920s:

The Negro woman is conscious that what is left of chivalry is not directed towards her. Instead, the grotesque Aunt Jemimas of the street-car advertisements proclaim only her ability to serve, without grace or loveliness. She if most often used to provoke mirthless laughter or ridicule or to portray feminine viciousness not peculiar to Negroes (Hancock, 2016, p. 166)

As such, Calpurnia is important as long as she remains unheard. Alexandra fails to fathom the possibility of the woman exerting any positive influence on the children, indicating that she should be dismissed because Atticus is raising a girl (Lee, 1960). Perhaps, in her perspective, Scout deserves a more acceptable role model- such as herself- to guide her perceptions and views as she transitions into adulthood (Lee, 2010). This inadequacy, therefore, is not limited to Calpurnia's status as a Negro, but it escalates the bias to disqualify her as a woman and a mother. This reflects the nature of the controlling images that have continuously been used over time to make racism, poverty, and sexism appear as natural components of everyday life (Hancock, 2016, p. 168) and their intersectionality more acceptable to those exploiting it for the discrimination of others.

Even more conspicuous is Harper Lee's portrayal of Helen Robinson, Tom's widow and the black woman working for Link Deas. Following the completion of the trial, Bob Ewell engages in overt threats and interference with the people he feels ridiculed him during the court process. While he indirectly attacks Atticus through accusations of taking his job and Judge Taylor through a discreet attack, he is less discreet in his attacks on Helen. He forces Helen to take an alternative route, imposing additional difficulties on her as she has to take care of her children too and the longer route is strenuous (Lee, 1960, p. 183). This constant attack is stopped by Link Deas, but it does little to cover the suffering that this woman must encounter in the wake of the death of her husband. It is unlikely that a similar outcome would be recorded by Tom had Hellen been the one that faced the guilty verdict, on account of his being male, or by a white woman whose husband was facing jail time or execution. These perspectives continually accentuate the suffering experienced by black women, with their race and gender weighing against them. The intersection between Helen's race, 


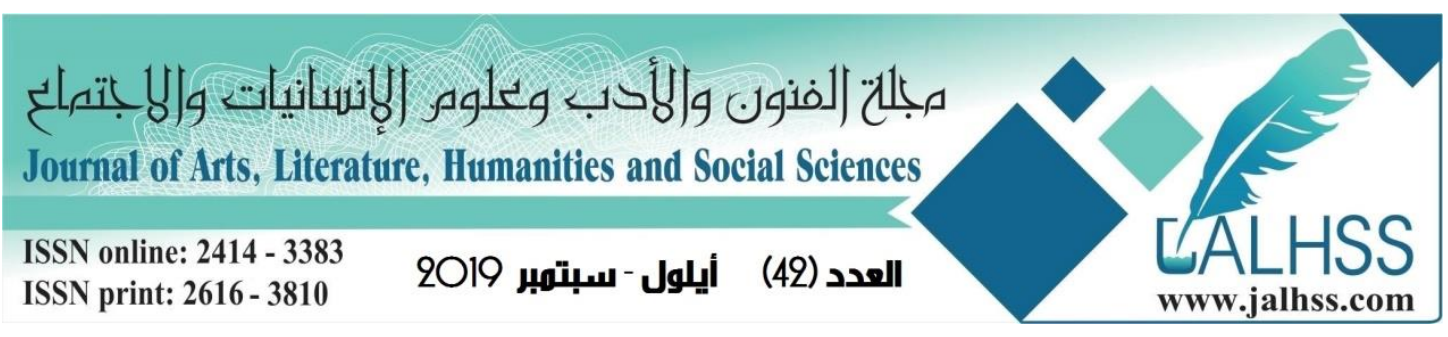

gender, as well as her lowly status as a cook, increases her susceptibility to Ewell's harassment. Ultimately, the experience fulfils the implications of critical race theory and its foundations regarding the vulnerabilities of the black woman (Delgado \& Stefancic, 2017).

The overlapping of classification or categories makes the actions and outcomes of other characters in Harper Lee's narrative particularly intriguing. The fate of Boo, for example, provides the basis for the assessment of the role of class and race in the determination of the experience of bias. The core premise of intersectionality is the need for the consideration of multiple determinant factors as the basis for the construction of an identity (Burton, et al., 2010, p. 446). Boo gets away with the assault case against him initially, which can be attributed to the unwillingness of his family to press charges (Lee, 2010). Nevertheless, after the murder of Bob Ewell, a similar outcome is perceptible (Lee, 1960). The death is ruled accidental and, as much as it favors the feelings of the reader, it presents a conundrum of sorts regarding the role his race and class have in the determination of this outcome. Contrasting the case of Tom Robinson with Boo's, where the victim and perpetrator were family members, could elucidate the difference in outcomes. However, evidence from the wider social context where other black people are subject to unjustified discrimination in Maycomb and the opinions of the people on Atticus' nature as a "nigger-lover" demonstrate the implications of race on the process of justice. Perhaps Lee recognizes the potential differences elicited by the characters of Boo and Tom Robinson that could justify difference in their judicial treatment (with family conflicts being resolved without prosecution) and seeks to offer the opportunity for clarification in the form of Helen's experience with further harassment and the failure to prosecute Bob Ewell.

The characters of Boo, Bob, and Tom offer a perspective into the social stratification of Maycomb and the influence of the strata on social outcomes. Bob is a classless white man, Boo relatively has more class but is also white, while Tom is poor and black. Evidently, the status of Boo as white and relatively wealthier guarantees the reluctance of the authorities to have him in jail alongside poor Negroes. Bob, on the other hand, faces the threat of prosecution especially after his confrontation of Hellen; perpetuated by the widespread knowledge of his family's lack of class. As a poor black man, Tom faces the worst possible outcomes within the social strata.

The differences accentuate the fact that bias is often the result of multiple interacting factors, as opposed to the singular influence of race in context (Gillborn, 2015, p. 279). Where multiple factors interact or overlap for a single individual, the outcomes are likely to change. The perspective makes the case for possible improvements to the fate of the minority through the equality of outcomes (Delgado \& Stefancic, 2017, p. 165). This is where improvements to areas such as wealth and education have the capacity to enable better coping with race and the bias that stems from racism. Critics of the CRT have argued that there lacks sufficient explanation of these outcomes manifesting in the presence of the deliberate improvements to wealth and educational 


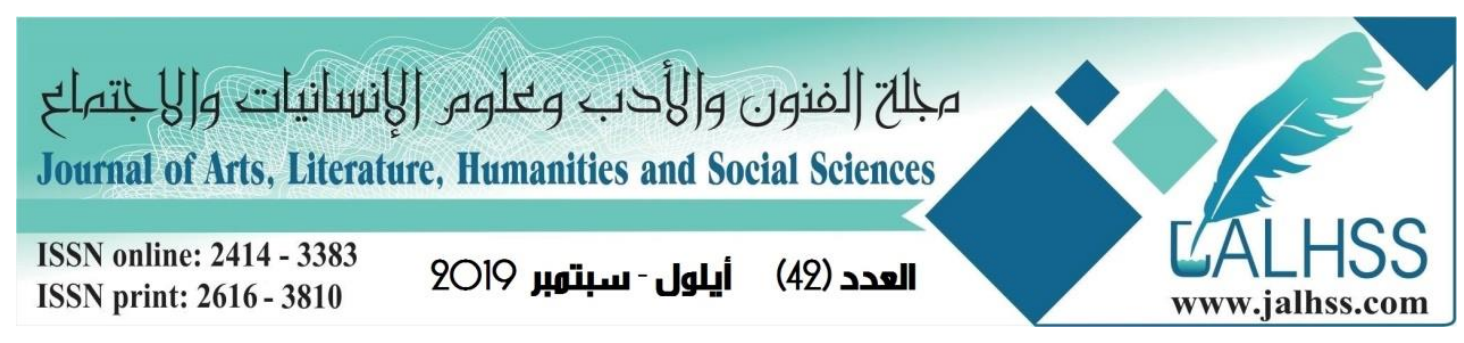

status; potentially discrediting such social reform as an approach to easing the burden of racism (Maisuria, 2012, p. 86).)

Nevertheless, it is evident that in a world where the expression of racism and the associated discrimination varies with individual factors, addressing other issues in the social context could be the basis for improvement (Crenshaw, 1988). Perhaps, in improving the wealth status of the African-American community in Maycomb, there may have been chances of Tom Robinson getting a more favorable outcome or eliciting more commitment from the jury.

\section{Conclusion}

The paper applies the Critical Race Theory towards establishing the roles of gender, historical position, social and economic factors in determining outcomes for the minority within the justice system in the United States. The law assumes equality for everybody, where a black man like Tom Robinson would be declared innocent as long as the evidence is in his favor. However, as long as the status quo of prejudice and stereotyping remains, it is unlikely for a black man to win against a white man- or woman, especially with an all-white jury present. This implication in Harper Lee's narrative can only make the case for the disillusioned poor black man, while perpetuating the recognition of the multiple factors that work against him towards the constancy of injustice for him. At the same time, the cautionary tale of the white people only perpetuating minority interests where it is likely to favor their own, manifests in this narrative. The novel thus makes the case for a justice system based on the actual minority interests.

\section{References}

1. Bell, D., 1980. Brown v. Board of Education and the interest-convergence dilemma. Harvard Law Review, Volume 93, pp. 518-533.

2. Bell, D., 1992. Race, racism and American law (3rd ed.). Boston : Little, Brown.

3. Billings, G. L. \& Tate-IV, W., 1995. Toward a Critical Race Theory in Education. Teachers College Record, 47(1), pp. 47-68.

4. Burton, L. M. et al., 2010. Critical Race Theories, Colorism, and the Decade's Research on Families of Color. Journal of Marriage and Family, 72(3), p. 440 - 59.

5. Crenshaw, K., 1988. Race, reform, retrenchment: Transformation and legitimation in anti-discrimination law. Harvard Law Review, Volume 101, pp. 1331-1387..

6. Delgado, R. \& Stefancic, J., 2000. Introduction. In: R. Delgado \& J. Stafancic, eds. Critical race Theory: The cutting edge. Philadelphia, PA: Temple University Press, pp. 1-14.

7. Delgado, R. \& Stefancic, J., 2017. Critical Race Theory (Third Edition): An Introduction, New York: NYU Press.

8. Gillborn, D., 2015. Intersectionality, critical race theory, and the primacy of racism: Race, class, gender, and disability in education. Qualitative Inquiry, 21(3), pp. 277287. 


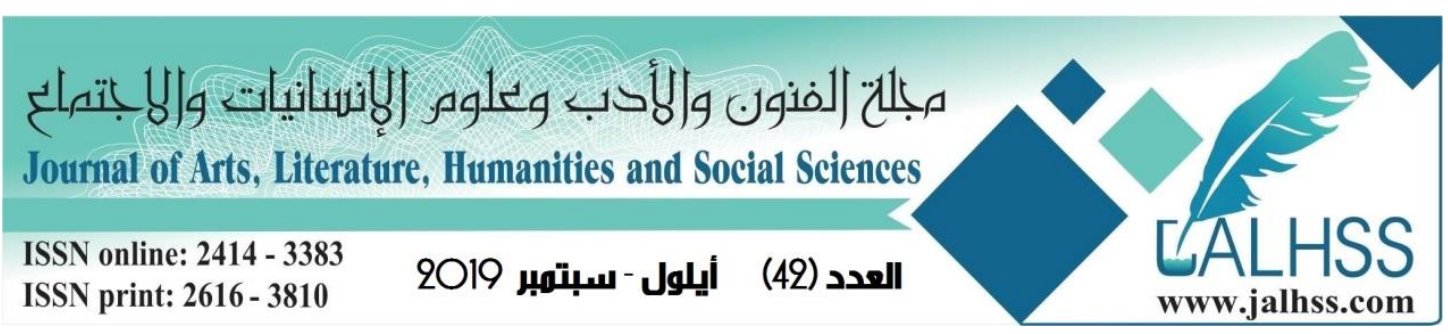

9. Gotanda, N. \& Peller, G., 1995. Critical race theory: The key writings that formed the movement. Washington: The New Press.

10. Greenbalt, S., 1988. Invisible Bullets: Rennaisance authority and its subversion, Henry Iv and Henry V. New York: Taylor and Francis.

11. Hancock, A.-M., 2016. Intersectionality: An Intellectual History. Oxford: Oxford University Press.

12. Harris, C., 1993. Whiteness as property. Harvard Law Review, Volume 106, pp. 1707-1791.

13. Irby, B., Brown, G. H., LaraAiecio, R. \& Jackson, D. S. A., 2013. Handbook of Educational Theories. Washington: IAP.

14. Lee, H., 1960. To Kill a Mockingbird, New York: Grand Central Publishing.

15. Lee, H., 2010. Harper Lee's To Kill a Mockingbird. Washington: Infobase Publishing.

16. Lee, H., 2015. Go Set a Watchman. UK: William Heineman.

17. Macaluso, M. \& Macaluso, K., 2018. Teaching the Canon in 21st Century Classrooms: Challenging Genres. New York: Brill.

18. Maisuria, A., 2012. A critical appraisal of critical race theory (CRT): Limitations and opportunities. In: K. Bhopal \& J. Preston, eds. Intersectionality and "race" in education. London, England: Routledge, pp. 76-96.

19. Matsuda, M. J., Lawrence, C. R., Delgado, R. \& Crenshaw, K. W., 1993. Words that wound: Critical race theory, assaultive speech, and the first amendment. Boulder, CO: Westview Press.

20. Peller, G., 1995. Critical Race Theory: The Key Writings that Formed the Movement. New York: The New Press.

21. Zwick, P., 2010. Rethinking Atticus Finch. Case W. Res. L. Rev, Volume 60 , pp. 1349-1360. 